\title{
Transverse Abdominis Plane Block-based Multimodal Analgesia Protocol Reduces Tramadol Need After Cesarean Section
}

\author{
Transvers Abdominis Plan Bloğu Tabanlı Multimodal Analjezi Protokolü, \\ Sezaryen Sonrası Tramadol İhtiyacını Azaltır
}

\section{(D) Savas Comlek}

Gayrettepe Florence Nightingale Hospital, Clinic of Anesthesiology, İstanbul, Turkey

\section{Abstract}

Objective: Various strategies of multimodal analgesia exist for pain control following caesarean section, aiming to improve analgesia, reduce opioid requirement, and therefore decrease the incidence of opioid related side effects. This study aimed to compare the analgesic quality and reduction in tramadol need across four different multimodal analgesia strategies after caesarean section with general anesthesia.

Method: A total of 160 patients that underwent elective cesarean section under general anesthesia were retrospectively included in one of the following groups: only tramadol-based patient-controlled analgesia, tramadol-based patient-controlled analgesia plus diclofenac suppository, tramadol-based patient-controlled analgesia plus diclofenac suppository plus paracetamol, and tramadol-based patient-controlled analgesia plus diclofenac plus transverse abdominis plane block. Visual analogue scale scores and tramadol use were monitored and recorded at $2^{\text {nd }}, 4^{\text {th }}, 8^{\text {th }}, 12^{\text {th }}$, and $24^{\text {th }}$ hours.

Results: At $2^{\text {nd }}, 4^{\text {th }}$ and $8^{\text {th }}$ hours, tramadol-based patient-controlled analgesia-only group had significantly higher visual analogue scale scores than all other groups $(p<0.05)$. At $24^{\text {th }}$ hour, transverse abdominis plane block group had lower scores than both tramadol-based patientcontrolled analgesia-only group and tramadol-based patient-controlled analgesia plus diclofenac group ( $p<0.01$ and $p=0.014$ ). Tramadol-based patient-controlled analgesia-only group had the highest and transverse abdominis plane block group had the lowest cumulative tramadol dose at all time points $(p<0.05)$, the remaining two groups were similar $(p>0.05)$.

Conclusion: Tramadol-based patient-controlled analgesia alone does not seem to provide effective pain control following caesarean section under general anesthesia. Multimodal analgesia including transverse abdominis plane block distinguishes itself with its most marked opioid-

\section{Öz}

\begin{abstract}
Amaç: Sezaryen sonrası postoperatif ağrı tedavisinde, opioid ihtiyacını azaltmayı ve dolayısıyla opioidle ilişkili yan etkilerin insidansını azaltmayı amaçlayan çeşitli multimodal analjezi stratejileri mevcuttur. Bu çalışma, genel anestezi ile sezaryen olan hastalarda uygulanan dört farklı multimodal analjezi stratejisinde, tramadol ihtiyacındaki azalmayı ve analjezi kalitesini karşılaştırmayı amaçladı.
\end{abstract}

Yöntem: Genel anestezi altında elektif sezaryen yapılan toplam 160 hasta geriye dönük olarak şu gruplardan birine dahil edildi: sadece tramadol bazlı hasta kontrollü analjezi, tramadol bazlı hasta kontrollü analjezi artı diklofenak fitil, tramadol bazlı hasta- kontrollü analjezi artı diklofenak fitil artı parasetamol ve tramadol bazlı hasta kontrollü analjezi artı diklofenak artı transversus abdominis plan bloğu. Görsel analog skala skorları ve tramadol kullanımı 2., 4., 8., 12. ve 24. saatlerde izlenerek kaydedildi.

Bulgular: Ikinci, 4. ve 8. saatlerde, sadece tramadol kullanılan hasta kontrollü analjezi grubu diğer tüm gruplardan anlamlı olarak daha yüksek görsel analog skala puanlarına sahipti $(p<0,05)$. Yirmi dördüncü saatte, transversus abdominis plan bloğu grubu, hem tramadol bazlı hasta kontrollü analjezi grubu hem de tramadol bazlı hasta kontrollü analjezi artı diklofenak grubundan daha düşük skorlara sahipti $(p<0,01$ ve $p=0,014)$. Kümülatif tramadol tüketimi, tramadol temelli hasta kontrollü analjezi alan grupta en yüksek, transversus abdominis plan bloğu grubunda ise tüm zaman noktalarında en düşük düzeyde olarak görülürken $(p<0,05)$, kalan iki grubun tüketimleri benzerdi $(p>0,05)$.

Sonuç: Tramadol bazlı hasta kontrollü analjezi tek başına genel anestezi altında sezaryen sonrası etkili ağrı kontrolü sağlamamaktadır. Transversus abdominis plan bloğu tabanlı multimodal analjezi protokolü, en belirgin opioid koruyucu etkiye sahipken, parasetamol ek fayda sağlamıyor gibi görünmektedir.

Address for Correspondence: Savas Comlek, Gayrettepe Florence Nightingale Hospital, Clinic of Anesthesiology, İstanbul, Turkey E-mail: savatc@gmail.com ORCID: orcid.org/0000-0002-7741-8400 Received: 12.11.2020 Accepted: 23.01.2021

Cite this article as: Çömlek S. Transverse Abdominis Plane Block-based Multimodal Analgesia Protocol Reduces Tramadol Need After Cesarean Section. Bagcilar Med Bull 2021;6(2):134-141

${ }^{\odot}$ Copyright 2021 by the Health Sciences University Turkey, Bagcilar Training and Research Hospital Bagcilar Medical Bulletin published by Galenos Publishing House. 


\section{Abstract}

sparing effect, while paracetamol does not appear to provide additional benefits.

Keywords: Cesarean section, diclofenac, paracetamol, patient-controlled analgesia, tramadol, transverse abdominis plane block

\section{Öz}

Anahtar kelimeler: Diklofenak, hasta kontrollü analjezi, parasetamol, sezaryen, tramadol, transversus abdominis plan bloğu

\section{Introduction}

Proper management of postoperative pain caused by cesarean section results in improved patient satisfaction, early mobilization, and better bonding between the mother and infant. Despite many proposed management strategies, multimodal approach forms the cornerstone of the current treatment (1).

Patient controlled analgesia (PCA) with intravenous (IV) opiates is a well-established component of postoperative pain management following caesarean section or labor, particularly for patients receiving single dose spinal anesthesia or general anesthesia during the procedure. However, systemic use of high dose opiates is associated with adverse effects ranging from pruritis, nausea, and vomiting to sedation and respiratory depression $(2,3)$. Tramadol, on the other hand, is a central analgesic with mixed opioid and non-opioid activity that has been reported to be associated with lower rates of neonatal respiratory depression as compared to other narcotics (4). Tramadol administration via IV PCA or continuous infusion provides effective early postoperative analgesia in patients undergoing caesarean section (5). Therefore, IV tramadol use for PCA not only provides satisfactory pain control, but also is preferred owing to its advantages in terms of respiratory depression, sedation, and intestinal motility (5). Nevertheless, high dose tramadol is known to be potentially associated with seizures as well as nausea/ vomiting (6).

The objective of multimodal analgesia is to augment the analgesic effect, reduce the opioid dosage required for pain relief, and therefore decrease the incidence of opioid related side effects (7). Non-steroid anti-inflammatory drugs (NSAIDs) and paracetamol are among the main constituents of this approach and contribute to postoperative analgesia by significantly reducing morphine use (8). Furthermore, supplementary use of NSAIDs after caesarean section/labor is particularly valuable due to their ability to alleviate pain caused by uterine contractions $(9,10)$. Transversus abdominis plane (TAP) block represents one of the abdominal field block techniques used for the treatment of postoperative pain after lower abdominal surgery. TAP-block has been most commonly used after caesarean section for postoperative pain control and to reduce the need for analgesia and incidence of side effects (11).

This study aimed to compare different analgesia strategies added on top of patient-controlled analgesia (PCA) with IV tramadol, in terms of their analgesic outcomes as well as tramadol sparing effects, in patients that undergoing cesarean section with general anesthesia.

\section{Materials and Methods}

\section{Patients}

A total of 160 patients with American Society of Anesthesiologists physical status of I-II undergoing elective caesarean section under general anesthesia were included. Subjects who received PCA with tramadol between 2014 and 2019 were screened. The following four multimodal treatment groups were defined and retrospectively 40 patients were included in each group: Only PCA with tramadol (TrPCA), TrPCA plus diclofenac suppository, TrPCA plus diclofenac suppository plus paracetamol, and TrPCA plus TAP-block. The study protocol was approved by the local ethics committee.

\section{Anesthesia Management}

Prior to general anesthesia, an 18G IV cannula was used to gain venous access for physiological saline infusion. In all three patient groups, induction was achieved with propofol $2 \mathrm{mg} / \mathrm{kg}$ (Propofol 1\%, Fresensius Kabi, Istanbul, Turkey), followed by curarization with rocuronium bromide $0.6 \mathrm{mg} / \mathrm{kg}$ (Esmeron, Merck Sharp \& Dohme, Istanbul, Turkey), intubation, and mechanical ventilation. After caesarean section and delivery were completed, all patients received fentanyl $1.5 \mathrm{mg} / \mathrm{kg}$ (Fentanyl $0.05 \mathrm{mg} / \mathrm{mL}$, Johnson and Johnson, Istanbul, Turkey) as a part of the anesthesia protocol. Also, based on the discretion of the obstetrician, 10 IU oxytocin was administered intravenously to support uterine contractions. 


\section{Postoperative Analgesia Protocols}

PCA with tramadol was administered to all patients undergoing caesarean section under general anesthesia. Following the completion of surgery and at the discretion of the attending anesthesiologist, one of the four main postoperative analgesia protocols of our unit was administered just prior to the termination of general anesthesia. The first protocol involved PCA with tramadol alone. The second group received additional diclofenac $100 \mathrm{mg}$ as a suppository, followed by a second dose after 12 hours. The third group received additional diclofenac suppository plus paracetamol $0.5 \mathrm{mg}$ IV every 6 hours, with the first dose being given just before the termination of anesthesia. The fourth group received additional diclofenac suppository plus transverse abdominis plane block via 20 cc $0.25 \%$ bupivacaine injection to both sides, performed under ultrasound guidance just prior to the termination of anesthesia. In all groups, tramadol (Contramal, Abdi Ibrahim, Istanbul, Turkey) administered via PCA comprised the main component of the postoperative pain treatment protocol. Before patients regained consciousness, a bolus $0.5 \mathrm{mg} / \mathrm{kg}$ dose of tramadol was administered in all groups. PCA was scheduled with 10-minute lock time and $20 \mathrm{mg}$ bolus doses. The 4 -hour limit was not used. The control button of the PCA device was supplied to patients after the completion of the recovery from anesthesia.

\section{Assessments}

Sedation scores, visual analogue scale (VAS) scores, and tramadol use were monitored for 24 hours and recorded at $2^{\text {nd }}, 4^{\text {th }}, 8^{\text {th }}, 12^{\text {th }}$, and $24^{\text {th }}$ hours using the PCA follow-up form. Also, side effects such as nausea, vomiting, pruritis, or atony were recorded. VAS scores were measured using a $10 \mathrm{~cm}$ visual scale. For sedation, the following scoring was used: 1) conscious, 2) occasional drowsiness, 3) frequent drowsiness, 4) sleeping but easily awakened, 5) sleeping but awakened with difficulty. A score of $>2$ recorded at any timepoint during the 24-h observation period was considered sedation, while nausea or vomiting was considered to occur if at least one episode was recorded.

\section{Statistical Analysis}

For data analysis, SPSS (Statistical Package for Social Sciences) version 21 software was used. Hypothesis tests and graphical methods were used to test normality. Between-group comparisons of continuous variables were done using One-Way analysis of variance (ANOVA) or the Kruskal-Wallis test, depending on data distribution. The Pearson chi-square test was used for the between-group comparison of categorical variables. Two-Way ANOVA test for repeated measurements was used to examine the significance of changes and differences between the groups in VAS scores and cumulative tramadol doses over time. Between-subject comparisons at different time points were done using the Kruskal-Wallis test and post hoc tests were done using built-in pairwise comparisons of the KruskalWallis test. Two-sided p-values $<0.05$ were considered as the indication of statistical significance.

\section{Results}

\section{Patients}

Table 1 shows preoperative demographical and clinical characteristics. The only parameter that the groups differed was the duration of cesarean section $(\mathrm{p}<0.001)$. TrPCA plus diclofenac plus TAP-block group had significantly longer duration when compared to all other groups $(\mathrm{p}<0.001$ for all comparisons).

\section{Table 1. Preoperative patient characteristics}

\begin{tabular}{|c|c|c|c|c|c|}
\hline Characteristics & TrPCA only & TrPCA + diclofenac & $\begin{array}{l}\text { TrPCA + diclofenac + } \\
\text { paracetamol }\end{array}$ & $\begin{array}{l}\text { TrPCA + diclofenac + } \\
\text { TAP-block }\end{array}$ & $\mathbf{p}$ \\
\hline Age, y & $31.2 \pm 4.6$ & $31.4 \pm 4.5$ & $31.1 \pm 4.3$ & $31.0 \pm 4.3$ & $0.964^{*}$ \\
\hline $\mathrm{BMI}, \mathrm{kg} / \mathrm{m}^{2}$ & $27.2 \pm 4.1$ & $27.2 \pm 3.6$ & $27.0 \pm 3.1$ & $27.0 \pm 1.1$ & $0.975^{*}$ \\
\hline $\mathrm{SBP}, \mathrm{mmHg}$ & $126.5 \pm 8.6$ & $126.0 \pm 8.4$ & $125.8 \pm 9.3$ & $124.8 \pm 9.6$ & $0.663^{*}$ \\
\hline $\mathrm{DBP}, \mathrm{mmHg}$ & $75.3 \pm 7.0$ & $74.8 \pm 6.6$ & $75.5 \pm 6.7$ & $75.3 \pm 6.8$ & $0.945^{*}$ \\
\hline $\mathrm{MAP}, \mathrm{mmHg}$ & $90.6 \pm 6.8$ & $90.1 \pm 6.5$ & $90.5 \pm 6.6$ & $90.0 \pm 6.8$ & $0.978^{*}$ \\
\hline Gestational age, weeks & $38.4 \pm 0.8$ & $38.5 \pm 0.8$ & $38.5 \pm 0.9$ & $38.5 \pm 0.9$ & $0.973^{*}$ \\
\hline CS duration, min. & $41.5 \pm 7.5$ & $42.3 \pm 7.8$ & $43.9 \pm 9.0$ & $55.1 \pm 8.4$ & $<0.001^{*}$ \\
\hline Multiparity, n (\%) & $20(50.0 \%)$ & $21(52.5 \%)$ & $20(50.0 \%)$ & $20(50.0 \%)$ & $0.995^{\ddagger}$ \\
\hline
\end{tabular}

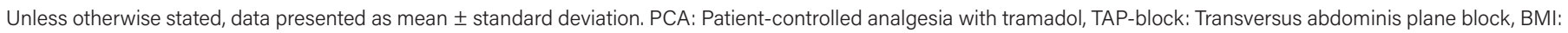

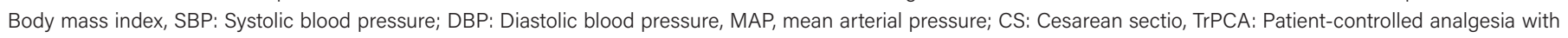
tramadol. Each group has 40 patients. P-values are from Kruskall-Wallis $\left({ }^{*}\right)$, One-Way ANOVA $\left(^{+}\right)$, or Pearson's chi-square test 


\section{Changes in VAS Scores}

Figure 1 shows the changes in mean VAS scores over time. There was a significant difference between the groups in terms of changes in VAS score over time $(\mathrm{p}<0.001)$. At $2^{\text {nd }}$, $4^{\text {th }}$ and $8^{\text {th }}$ hours, TrPCA group had significantly higher scores than all other groups ( $\mathrm{p}<0.05$ for all), but at $12^{\text {th }}$ hour, the groups had similar scores. At $24^{\text {th }}$ hour, TrPCA plus diclofenac plus TAP-block group had lower scores than both TrPCA and TrPCA plus diclofenac groups $(\mathrm{p}<0.001$ and $\mathrm{p}=0.014)$.

\section{Changes in Tramadol Requirement}

Figure 2 shows the changes in cumulative tramadol dose over time. There was a significant difference between the groups in terms of changes in cumulative tramadol dose over time $(\mathrm{p}<0.001)$. TrPCA group had the highest and TrPCA plus diclofenac plus TAP-block group had the lowest cumulative tramadol dose at all time points $(\mathrm{p}<0.05$ for all); however, the remaining two groups had similar cumulative doses over time ( $>0.05$ for all). At $24^{\text {th }}$ hour, cumulative tramadol doses for the groups were as follows: TrPCA, 357.0 $\pm 58.3 \mathrm{mg}$, TrPCA plus diclofenac, 289.0 \pm 54.7 mg, TrPCA plus diclofenac plus paracetamol, 261.0 \pm 41.5 $\mathrm{mg}$, and TrPCA plus diclofenac plus TAP-block, 203.0 \pm 33.5 mg. Thus, TrPCA plus diclofenac plus TAP-block resulted in $43 \%, 30 \%$, and $22 \%$ reduction in cumulative dose when compared to TrPCA, TrPCA plus diclofenac, and TrPCA plus diclofenac plus paracetamol group, respectively.

\section{Side Effects}

Table 2 shows the distribution of side effects across the groups. The differences of the frequencies of sedation,

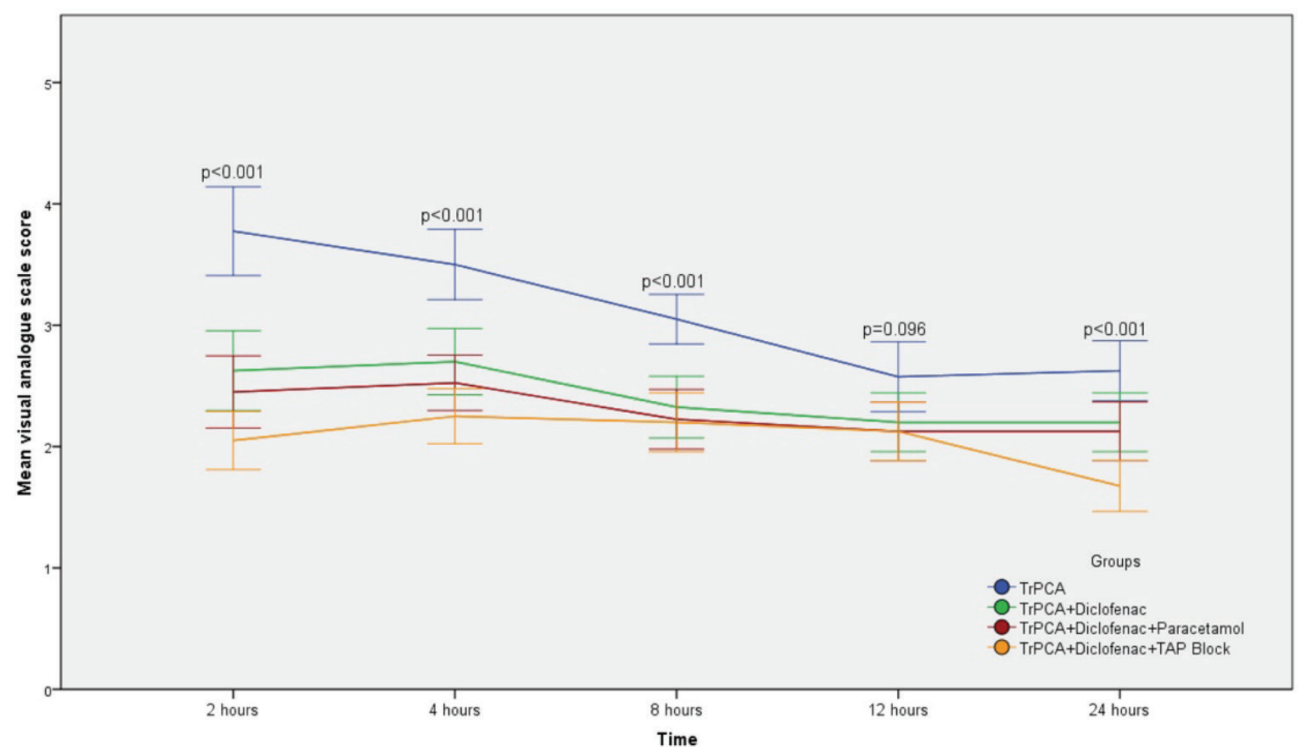

Figure 1. Changes in mean VAS scores over time. Error bars indicate 95\% confidence intervals. p-value for Two-Way ANOVA for repeated measurements is $<0.001$, indicating a significant difference between groups in terms of changes in VAS score over time. p-values on the figure indicates significance of overall differences between groups at specific time points, which were obtained from Kruskal-Wallis test. To avoid confusion, p-values for pairwise comparisons at each time point is given in the text.

TrPCA: Patient-controlled analgesia with tramadol, TAP-block: Transversus abdominis plane block, VAS: Visual analog scale

Table 2. Frequencies of side effects

\begin{tabular}{llllll} 
Side effect & PCA only & $\begin{array}{l}\text { PCA }+ \\
\text { diclofenac }\end{array}$ & $\begin{array}{l}\text { PCA + diclofenac } \\
\text { + paracetamol }\end{array}$ & $\begin{array}{l}\text { PCA + diclofenac + } \\
\text { TAP-block }\end{array}$ \\
\hline Sedation* & $1(2.5 \%)$ & 0 & 0 & 0 & 0.389 \\
Nausea/vomiting & $6(15.0 \%)$ & $2(5.0 \%)$ & $2(5.0 \%)$ & $2(5.0 \%)$ & 0.229 \\
Pruritis & $3(7.5 \%)$ & $1(2.5 \%)$ & $3(7.5 \%)$ & $2(5.0 \%)$ & 0 \\
Uterine atony & $1(2.5 \%)$ & $1(2.5 \%)$ & $1(2.5 \%)$ & 0.730 & 0.797 \\
Any side effect & $10(25.0 \%)$ & $4(10.0 \%)$ & $6(15.0 \%)$ & $4(10.0 \%)$ & 0.195 \\
\hline
\end{tabular}

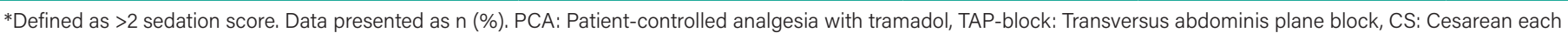
group has 40 patients. *p-values are from Pearson's chi-square test* 
nausea/vomiting, pruritis, uterine atony as well as the frequency of any side effect did not reach statistical significance. However, when the groups were combined, the frequency of any side effect was higher in patients that received PCA only when compared to other patients that had add-on treatments $(25.0 \%$ vs. $11.7 \%, \mathrm{p}=0.041)$. On the other hand, the frequency of any side effect was not significantly different in the TrPCA plus diclofenac plus TAP-block group when compared to the rest of the patients $(\mathrm{p}=0.306)$.

\section{Discussion}

The findings of our study suggest that PCA with tramadol only was unable to provide adequate postoperative pain control in patients undergoing caesarean section under general anesthesia and that a management strategy based on multimodal analgesia may allow better pain control and reduced need for tramadol. To the best of our knowledge, this is the first study to examine such a high number of multimodal analgesia strategies in patients who underwent caesarean section with general anesthesia and received tramadol based IV PCA.

Opiates are administered via IV PCA following caesarean section to provide analgesia. However, it is important to limit postoperative need for opiates due to their wellestablished side effects such as sedation, nausea, and vomiting $(2,3,12)$. Furthermore, opiates may also have adverse effects on the newborns (13). Therefore, not only the choice of suitable agents, but also reducing the need for opiates are clinically important considerations with respect to mother and infant health in this setting.

Tramadol, which has been shown to be quite effective for postoperative analgesia with synergistic effects when combined with non-opioid analgesics, has also been reported to be effective and safe when used for caesarean section $(5,14,15)$. Its effects on the cardiovascular and respiratory systems are less pronounced as compared to equivalent doses of other opioids $(16,17)$, which renders this agent suitable for multimodal analgesia. However, tramadol may still be associated with some opioid-type side effects. For instance, in the study by Mitra et al. (18) comparing diclofenac/tramadol and diclofenac/acetaminophen for pain management after caesarean section, both treatments were found to be effective, although there was a higher incidence of postoperative nausea among patients who received diclofenac/tramadol. Furthermore, tramadol may be associated with seizures (6) and shows limited efficacy in severe pain (1). Therefore, improving multimodal analgesia with non-opiate and opiate combinations including

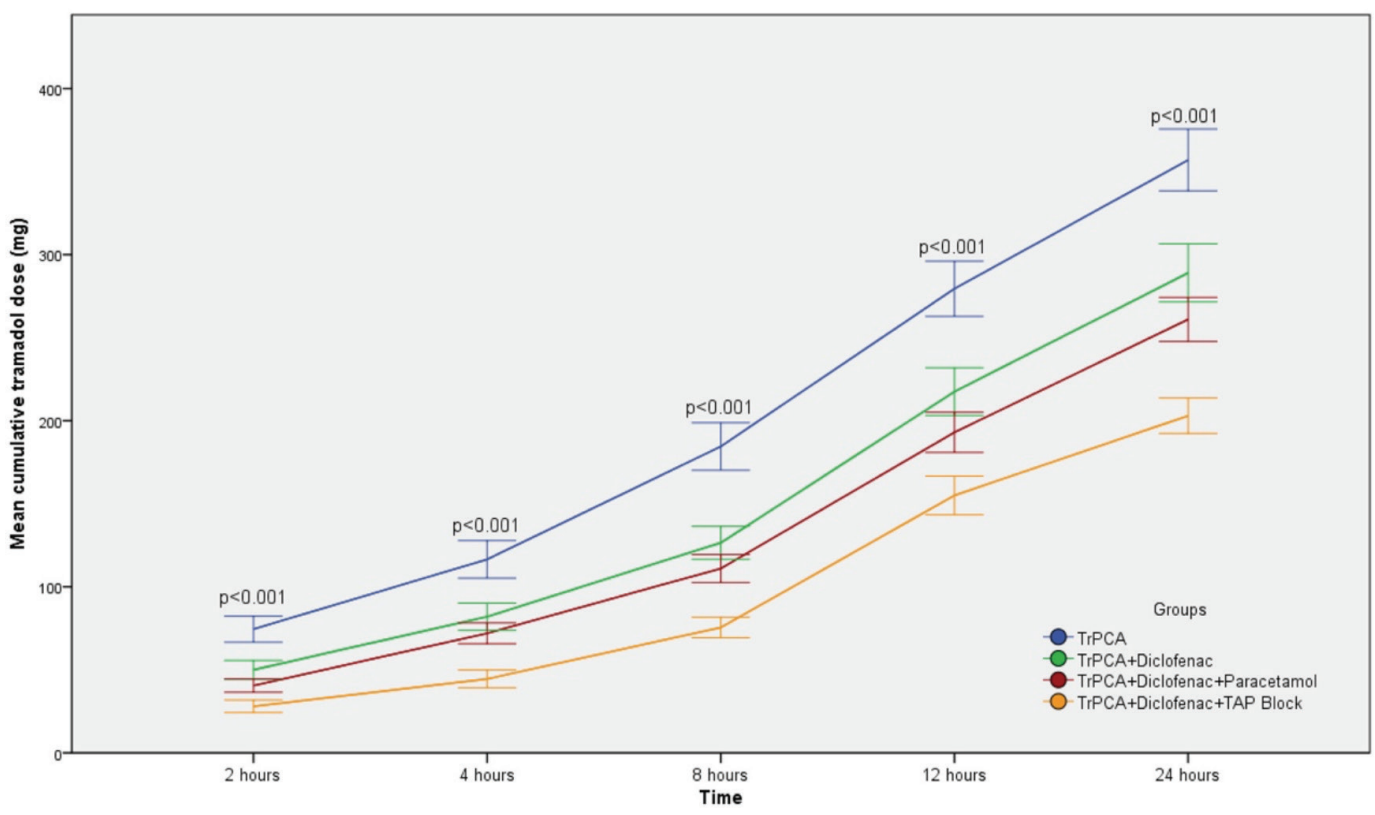

Figure 2. Changes in cumulative tramadol dose over time. Error bars indicate 95\% confidence intervals. p-value for TwoWay ANOVA for repeated measurements is $<0.001$, indicating a significant difference between groups in terms of changes in cumulative tramadol dose over time. p-values on the figure indicates significance of overall differences between groups at specific time points, which were obtained from Kruskal-Wallis test. p-values for pairwise comparisons at each time point is given in the text. To avoid confusion, p-values for pairwise comparisons at each time point is given in the text. 
regional analgesia strategies such as local anesthetic-based TAP-block, and/or other analgesic agents may represent a key for ideal postoperative analgesia.

TAP-block is the administration of local anesthetics into the anatomic neuro-fascial space between the internal oblique and transversus abdominus muscles in the antero-lateral abdomen, to block the anterior branches of thoracic inter-costal (T7-T12) and first lumbar nerves. As shown in multiple studies, this allows safe and effective blockade of the nerves responsible for the transmission of pain sensation from the area of intervention in caesarean section $(19,20)$. Although local anesthetic concentrations exceeding the safety limits have been detected in systemic circulation, systematic reviews have concluded that TAPblock is a relatively safe procedure (20). It has also been proposed that ultrasound-guided TAP-block may even be more effective and provide a means for more accurate nerve block, negating some of the side effects (19). Erbabacan et al. (21) observed comparable efficacy between TAP-block and IV PCA in patients undergoing lower abdominal surgery. However, these authors stated that when compared to IV PCA, TAP-block was preferable due to its ability to avoid systemic effects of morphine and due to more rapid onset of analgesic effects (21). Jadon et al. (22) in their doubleblind randomized study concluded that ultrasound-guided TAP-block reduced the pain due to caesarean section with spinal anesthesia, prolonged the time to first request of analgesia, and decreased the need for additional opioids when used as a component of a multimodal analgesia strategy (22). Although superior analgesia was reported by Kanazi et al. (23) for subarachnoid morphine administered as compared to ultrasound-guided TAP block as a part of multimodal analgesia, the former method was also found to be associated with some serious side effects including nausea/vomiting and pruritus. In many other studies, TAP-block was reported to provide safe analgesia, improve patient comfort, and reduce the need for tramadol in patients undergoing caesarean section $(9,11,24)$. In line with these findings, inclusion of TAP-block into multimodal strategy resulted in better analgesia and opioid-sparing effect in the present study.

NSAIDs are effective for the management of visceral pain caused by uterine contractions, which are an important factor for postoperative pain after caesarean section $(9,25)$. Diclofenac is one of the most important inhibitors of the cyclooxygenase enzyme. Although its analgesic effect is primarily based on peripheral inhibition of prostaglandin synthesis, it is also known to exert central effects $(26,27)$.
Although NSAIDs have been associated with a slightly prolonged increase in bleeding time when used for postoperative pain management, this is not clinically significant (28). Olofsson et al. (9) showed that diclofenac at a dose of $150 \mathrm{mg}$ administered over a 24-hour period as a part of multimodal analgesia strategy was associated with significantly reduced opiate use and improved analgesia quality in patients undergoing caesarean section, thus avoiding systemic side effects of opiates. Our findings also suggest that diclofenac may have a role in multimodal analgesia approach following cesarian section.

The analgesic activity of paracetamol, which also has antipyretic effects, is thought to occur via central anti-nociceptive mechanisms due to inhibition of cyclooxygenase-3, a purported variant of cyclooxygenase-1 (29). Paracetamol has a well-established efficacy and safety record and is considered a first-choice agent for the treatment of pain in pregnant or lactating women (30). Several studies have reported that paracetamol used in combination with tramadol following caesarean section may provide safe and effective analgesia and reduce the need for tramadol (31). On the other hand, Siddik et al., in their study investigating the effect of diclofenac and/or propacetamol on morphine doses administered via PCA, found that concurrent use of diclofenac with morphine based PCA improved analgesia quality, in addition to significantly reducing the need for morphine as compared to propacetamol and placebo (8). These authors showed that propacetamol itself, alone or in combination with diclofenac, did not contribute to the reduction in morphine requirement (8). Again, in the present study, while diclofenac was able to reduce tramadol use via PCA and to improve the quality of analgesia, paracetamol had no additional effects.

Pain after surgical procedures results from the direct trauma on neural structures as well as the stimulation of nociceptors. The roles of certain receptors, mediators, and neurotransmitters involved in central and peripheral sensitization after surgical incision have been relatively elucidated (32). When planning multimodal analgesia, these complex mechanisms and the involved receptors, mediators, and neurotransmitters should be taken into consideration as well as the need to prevent the development of chronic pain after surgery. Based on our results, TAP-block administered in conjunction with the peripherally acting diclofenac and centrally acting tramadol appears to provide the most effective analgesia together with minimized side effects. 


\section{Conclusion}

Tramadol administered through PCA alone only does not seem to provide effective pain control following caesarean section under general anesthesia. Multimodal analgesia targeting multiple pain mechanisms not only contributes to the quality of analgesia, but also reduces the need for tramadol. Among different approaches tested, multimodal analgesia including TAP-block distinguishes itself with its most marked opioid-sparing effect, while paracetamol does not appear to provide additional benefits.

\section{Ethics}

Ethics Committee Approval: It was approved by Demiroğlu Science University Clinical Research Ethics Committee (2020/9-7).

Informed Consent: It was a retrospective study.

Peer-review: Internally peer-reviewed.

Financial Disclosure: The author declared that this study has received no financial support.

\section{References}

1. Lavoie A, Toledo P. Multimodal postcesarean delivery analgesia. Clin Perinatol 2013;40(3):443-455.

2. Harrison DM, Sinatra R, Morgese L, Chung JH. Epidural narcotic and patient-controlled analgesia for post-cesarean section pain relief. Anesthesiology 1988;68(3):454-457.

3. Sharma SK, Sidawi JE, Ramin SM, Lucas MJ, Leveno KJ, Cunningham FG. Cesarean delivery: a randomized trial of epidural versus patient-controlled meperidine analgesia during labor. Anesthesiology 1997;87(3):487-494.

4. Fieni S, Angeri F, Kaihura CT, Ricci L, Bedocchi L, Galanti B, et al. [Evaluation of the peripartum effects of 2 analgesics: meperidine and tramadol, used in labor]. Acta Biomed Ateneo Parmense 2000;71(Suppl 1):397-400.

5. Demirel I, Ozer AB, Atilgan R, Kavak BS, Unlu S, Bayar MK, et al. Comparison of patient-controlled analgesia versus continuous infusion of tramadol in post-cesarean section pain management. J Obstet Gynaecol Res 2014;40(2):392-398.

6. Vadivelu N, Chang D, Helander EM, Bordelon GJ, Kai A, Kaye $\mathrm{AD}$, et al. Ketorolac, oxymorphone, tapentadol, and tramadol: a comprehensive review. Anesthesiol Clin 2017;35(2):e1-e20. doi: 10.1016/j.anclin.2017.01.001.

7. Elia N, Lysakowski C, Tramer MR. Does multimodal analgesia with acetaminophen, nonsteroidal antiinflammatory drugs, or selective cyclooxygenase-2 inhibitors and patient-controlled analgesia morphine offer advantages over morphine alone? Meta-analyses of randomized trials. Anesthesiology 2005;103(6):1296-1304.

8. Siddik SM, Aouad MT, Jalbout MI, Rizk LB, Kamar GH, Baraka AS. Diclofenac and/or propacetamol for postoperative pain management after cesarean delivery in patients receiving patient controlled analgesia morphine. Reg Anesth Pain Med 2001;26(4):310-315.
9. Olofsson CI, Legeby MH, Nygards EB, Ostman KM. Diclofenac in the treatment of pain after caesarean delivery. An opioid-saving strategy. Eur J Obstet Gynecol Reprod Biol 2000;88(2):143-146.

10. Varrassi G, Marinangeli F, Agro F, Aloe L, De Cillis P, De Nicola A, et al. A double-blinded evaluation of propacetamol versus ketorolac in combination with patient-controlled analgesia morphine: analgesic efficacy and tolerability after gynecologic surgery. Anesth Analg 1999;88(3):611-616.

11. Mishriky BM, George RB, Habib AS. Transversus abdominis plane block for analgesia after Cesarean delivery: a systematic review and meta-analysis. Can J Anaesth 2012;59(8):766-778.

12. Eisenach JC, Grice SC, Dewan DM. Patient-controlled analgesia following cesarean section: a comparison with epidural and intramuscular narcotics. Anesthesiology 1988;68(3):444-448.

13. Wittels B, Scott DT, Sinatra RS. Exogenous opioids in human breast milk and acute neonatal neurobehavior: a preliminary study. Anesthesiology 1990;73(5):864-869.

14. Chi X, Li M, Mei W, Liao M. Comparison of patient-controlled intravenous analgesia with sufentanil versus tramadol in postcesarean section pain management and lactation after general anesthesia - a prospective, randomized, double-blind, controlled study. J Pain Res 2017;10:1521-1527.

15. Edwards JE, McQuay HJ, Moore RA. Combination analgesic efficacy: individual patient data meta-analysis of single-dose oral tramadol plus acetaminophen in acute postoperative pain. J Pain Symptom Manage 2002;23(2):121-130.

16. Shipton EA. Tramadol-present and future. Anaesth Intensive Care 2000;28(4):363-374.

17. Scott LJ, Perry CM. Tramadol: a review of its use in perioperative pain. Drugs 2000;60(1):139-176.

18. Mitra S, Khandelwal P, Sehgal A. Diclofenac-tramadol vs. diclofenac-acetaminophen combinations for pain relief after caesarean section. Acta Anaesthesiol Scand 2012;56(6):706-711.

19. Baeriswyl M, Kirkham KR, Kern C, Albrecht E. The analgesic efficacy of ultrasound-guided transversus abdominis plane block in adult patients: a meta-analysis. Anesth Analg 2015;121(6):1640-1654.

20. Rahiri J, Tuhoe J, Svirskis D, Lightfoot NJ, Lirk PB, Hill AG. Systematic review of the systemic concentrations of local anaesthetic after transversus abdominis plane block and rectus sheath block. Br J Anaesth 2017;118(4):517-526.

21. Erbabacan E, Kendigelen P, Koksal GM, Tutuncu C, Ekici BB, Seker $\mathrm{TB}$, et al. Comparison of transversus abdominis plane block and IV patient-controlled analgesia after lower abdominal surgery. Turk J Anaesthesiol Reanim 2015;43(1):24-28.

22. Jadon A, Jain P, Chakraborty S, Motaka M, Parida SS, Sinha N, et al. Role of ultrasound guided transversus abdominis plane block as a component of multimodal analgesic regimen for lower segment caesarean section: a randomized double blind clinical study. BMC Anesthesiol 2018;18(1):53.

23. Kanazi GE, Aouad MT, Abdallah FW, Khatib MI, Adham AM, Harfoush DW, et al. The analgesic efficacy of subarachnoid morphine in comparison with ultrasound-guided transversus abdominis plane block after cesarean delivery: a randomized controlled trial. Anesth Analg 2010;111(2):475-481.

24. Kupiec A, Zwierzchowski J, Kowal-Janicka J, Gozdzik W, Fuchs $\mathrm{T}$, Pomorski $\mathrm{M}$, et al. The analgesic efficiency of transversus abdominis plane (TAP) block after caesarean delivery. Ginekol Pol 2018;89(8):421-424. 
25. Sun HL, Wu CC, Lin MS, Chang CF. Effects of epidural morphine and intramuscular diclofenac combination in postcesarean analgesia: a dose-range study. Anesth Analg 1993;76(2):284-288.

26. McCormack K. NSAI drugs and spinal nociceptive processing. Pain 1994;59(1):9-43.

27. McCormack K, Brune K. Dissociation between the antinociceptive and anti-inflammatory effects of the nonsteroidal antiinflammatory drugs. A survey of their analgesic efficacy. Drugs 1991;41(4):533-547.

28. Rorarius M, Miralles J, Baer GA, Palomaki E. Diclofenac versus indomethacin given as intravenous infusions: their effect on haemodynamics and bleeding time, and side-effects in healthy subjects. Ann Clin Res 1985;17(6):306-309.
29. Chandrasekharan NV, Dai H, Roos KL, Evanson NK, Tomsik J, Elton TS, et al. COX-3, a cyclooxygenase-1 variant inhibited by acetaminophen and other analgesic/antipyretic drugs: cloning, structure, and expression. Proc Natl Acad Sci U S A 2002;99(21):13926-13931.

30. Day RO, Graham GG, Whelton A. The position of paracetamol in the world of analgesics. Am J Ther 2000;7(2):51-54.

31. Kilicaslan A, Tuncer S, Yuceaktas A, Uyar M, Reisli R. [The effects of intravenous paracetamol on postoperative analgesia and tramadol consumption in cesarean operations]. Agri 2010;22(1):7-12.

32. Pogatzki-Zahn EM, Segelcke D, Schug SA. Postoperative pain-from mechanisms to treatment. Pain Rep 2017;2(2):e588. doi: 10.1097/ PR9.0000000000000588. 